\title{
Memories of Home: Reading the Bedouin in Arab American Literature
}

\author{
Anissa J. Wardi \\ Chatham College \\ Katherine Wardi-Zonna \\ Gannon University
}

In an urban neighborhood with a large Jewish population near my home, there is an Arabic restaurant. Name, menu and ownership mark its ethnic identification, yet its politics are otherwise obscured. An American flag, permanently placed in the restaurant's window since 9/11, greets American customers with a message of reconciliation. I am one of you, it says: come; eat; you are welcome here. In a climate where "Arabs, Arab-Americans and people with Middle Eastern features, everywhere are struggling to merely survive the United States' aggressive drive to 'bring democracy to the Middle East"' (Elia 160) and where the hostility toward Arab Americans is manifest in covert "othering" and aggressive acts of surveillance, detainment and bodily harm, the steady bustle of my neighborhood eatery is of consequence.

Looking beyond the commerce taking place in the restaurant, the temporary community established there suggests Arab hospitality, which, as the speaker of Naomi Shihab Nye's "Red Brocade" reminds us, is predicated on food. Recalling an old adage, the poem begins: "The Arabs used to say, / When a stranger appears at your door, I feed him three days / before asking who he is, / where he's come from, / where he's headed. I That way, he'll have strength / enough to answer. Or, by then, you'll be / such good friends/ you don't care" (40). This stanza epitomizes the role of food in Arab culture as that which unifies, makes friends out of strangers and invites the other into the sanctuary of home. In this way, as patrons enter my neighborhood restaurant, permeated by the sounds and smells of the Arab world, I question whether this arena and, more generally, the preparation and serving of food, are untouched by national politics. Ordering Arabic cuisine, digesting the food of the "other," suggests cultural intimacy, a shared understanding that perhaps unwittingly permits entrance into an Arab homespace, as food remains an objective correlative of family, culture, and geography. 
This topography of home is not lost on Arab customers who frequent the restaurant. For these patrons, the establishment provides a safe space where food and language transport them to their native homelands. Acting as a bridge, a conduit to the "old country," my neighborhood restaurant provides insight into the manifold ways in which the portable elements of home, though seemingly depoliticized, are imbued with deep cultural and historical resonances.

Home occupies both a literal and conceptual space in Arab American letters. Arab American writers' focus on the home can be understood in the context of postcolonial literature insofar as the politics of home, geography and displacement figure strongly in the tradition. Modern day Arab diasporic identity hinges upon alliance with Palestinians, exiled, displaced and uprooted. In fact, the speaker of Mohja Khaf's poem, "I Can Scent an Arab Man a Million Miles Away," recounts the many "good things" for which Arab men, as a collective, are noted: it is not surprising that the first trait is to "be politicized about Palestine / from the third grade, at the latest" (29). Solidarity with the Palestinians as a connective of Arabs worldwide is a thread of political unification which structures, in part, the modern Arab self. Thus, the demolition of Palestinian homes and villages and the continuing occupation of the West Bank and Gaza represent a dismantling and violent erasure of Arab identity as the Arab world's sense of home is not deterritorialized, but is firmly placed in various nation states of the Middle East, a geo-political conflation which recurs throughout the writing of Arab Americans.

Given the colonization of the Arab world, including Western occupation and its legacy, and the continuation of imperial wars, it is fitting that Arab American texts are centrally concerned with issues of citizenship, exile and homelands. In Home, Maison, Casa, Johnson offers the following: "An architectural as well as psychological, geographical as well as social concept, 'home' figures as a deeply personal and highly political theme underlying literary and critical narratives of empire. From imperial narratives which cast 'home countries' against colonial peripheries to changing narratives of national identity that have occurred in the aftermath of empires, 'home' emerges as a powerful if contested ideological force" (13). Because Arab American writers are themselves immigrants (some of whom are fleeing from war-torn countries)or first and second generation descendants of immigrants home, for them, is an unstable affair. Such writers are removed from their native land and residing in what is, at times, inhospitable terrain. That exile and displacement are the prisms through which we enter Arab American homelands reveal that home is not an uncomplicated space of sanctuary. Rather, in this literary geography, home is often paired with mourning, loss and death. Arab Americans' treatment of home is in line with other migrant literature insofar as "home figures as an absence"; in fact, "homesickness" is a hallmark of this literary expression (qtd. in Johnson 16).

While the Arab world recurs as a familial or ancestral location and is often embedded as a memory of home, it is Arab Americans' tenuous placement in America, the new home, that preoccupies much of the tradition. In Joseph Geha's Through and Through: Toledo Stories, the characters' desire for home is tempered with the realization that their American domiciles are haunted with absences. Further, and perhaps more significantly, the home of their memories is impossible to reestablish in this new land, and thus home becomes a site of loss even as it promises a new beginning. In Through and Through, it is not always geography that defines home; 
rather, certain characters, through their performance of cultural rituals, transcend temporal and geographic separation in order to become spaces of home; these characters are at home with themselves, and provide home for others. In this way, the Arab American literary tradition is in line with migrant literature which "articulate[s] a sense of home amidst homelessness by building on familial and communal ties" (Johnson 17).

Wars and other foreign policy decisions have precluded many immigrant and native born Arab Americans from making pilgrimages to ancestral lands. Because these journeys, or longed-for journeys, "hinge on the notion of return," they can be labeled as journeys of repatriation, a term which "refers to the return of a person or an object to her/its place of origin" (Johnson 20). That many Arab American writers are not literally returning to an originary place, but constructing the Middle East as the collective site of Arab origins, underlies the complexity of home as a constellation of inherited memory, family traditions and nostalgic longings. The many texts of home in Geha's short story collection-food, drink, language and dance-are material, ritualistic connections to the old country and their survival is due, in large part, to their portability. In this way, the very image of the Bedouin, one who literally carries home, provides a cultural lens for reading Geha's Through and Through. While this short story collection is the site of analysis in this paper, the image of the Bedouin is a useful paradigm for reading Arab American creative expression more expansively.

Although greatly mythologized in both the Western and Eastern imaginary, the Bedouin has and continues to be a very real presence in the Middle East. i" The very name Bedouin, translated to mean "dweller of the open land," or "desert dwellers" or, as they are customarily referred, "people of the tent," embodies movement.iii Shepherds and camel herders, these nomadic peoples move either seasonally or constantly. While many Bedouin tribes move together, some customs regarding kinship structure realize loss with movement: "Separations from loved ones are a fact of life. . . . For women, the most difficult separations, after their own from their natal families at marriage, are those from their children. Daughters marry and leave to live with their husbands' families. Their daughters' departure is hard on mothers, who lose companionship and household help" (Abu-Lughod 283). Currently there are Bedouins, for example in the Egyptian Western Desert, who are in the "process of sedentarization," and thus live as a minority "on the fringes of settled life" (Abu-Lughod 281).

Historically, the terms Arab and Bedouin were interchangeable. Throughout the pre-Christian and early Christian period, the term Arab signified Bedouin, and thus referenced "the nomadic as distinct from the sedentary population" (Lewis 4). Indeed, "[f]or Muhammad and his contemporaries, the Arabs were the Bedouin of the desert, and in the Qur'an the term [Arab] is used exclusively in this sense and never of the townsfolk of Mecca, Medina and other cities" (Lewis 5). Further, the Bedouin's language is regarded as "the purest form of Arabic," as they "have preserved more faithfully than any others the original Arab way of life and speech" (Lewis 5). In this way, Arab American writers resituate the Bedouin as a synecdoche of a collective Arab past. As immigrants or children of immigrants, it is fitting that Arab American writers look to the Bedouin, a figure of movement, as an ancestral antecedent to migration and survival. ${ }^{\text {iv }}$ 
Bedouin life was based in hardship: severe desert climates and the dangers presented by warring tribes made survival a daily concern for these nomadic peoples. Despite the laborious conditions of early Bedouin life, the community was steeped in poetry and other verbal arts: "In harsh nomadic conditions, unfavourable to arts like painting and sculpture, language was cherished as the supreme medium of creative expression. The poet was the soul of the tribe; he was its mouthpiece, its propagandist and its chronicler. ... Although writing was not unknown to the pre-Islamic Arabs, few of these poems were written down at the time. They were composed, sung and memorized at tribal gatherings and at great poetry contests" (Musallam 25). ${ }^{v}$ That these ancestors engaged in the art of bearing witness through the word further underscores their relevance for Arab American writers. ${ }^{\mathrm{vi}}$ As inheritors of this tradition of movement, hardship and creation, Arab American writers, implicitly and explicitly, resituate the Bedouin as a touchstone of their creative expression. Since Bedouin tribes are loyal to family and proud of ancestry, expressing "their cohesion and loyalty in the idiom of common ancestry" (Hourani 107), Arab American writers employ the figure of the Bedouin as a unifying ethnic marker.

Two Arab American poems, Saladin Ahmed's "Poem for Countee Cullen" and H.S. Hamod's "Moving" offer the Bedouin as the archetypal ancestral figure. Ahmed's poem signifies on Cullen's "Heritage," with Cullen's "jungle" paralleled with Ahmed's "desert." Being "three centuries removed," the speaker of "Heritage" questions the role that Africa plays in his life, with the refrain "What is Africa to me?" Although Cullen does not outright claim Africa as his native land, the speaker of Ahmed's poem insists that Africa is "home" to Cullen, just as the Middle East is to him, maintaining that "Neither of us / Has ever been there / For both of us / It is home." Since neither has seen their forebears' land, the speaker implicitly cites ancestry, a kind of blood memory, as access to these homelands, concretized in the repetition of the words "remember I remembering." Whereas Cullen hears "the echoes of tribal rhythms" in his memory, Ahmed "find[s] Bedouin." This simple, yet powerful utterance at once places Ahmed's home in a collective Arab past and also provides a key to the displacement in which the speaker is steeped. The poem, finally, is a reverie on marginalization and dislodgement, as both speakers-African American and Arab American-situate home as a site of longing.

The Bedouin metaphor is used more comprehensively in H.S. Hamod's "Moving," which registers the pain of homeland separation and cultural disinheritance. The poem is an elegy for a lost way of life, that of the speaker's father and grandfather. The speaker's children, living in American, are displaced from their Arab culture, illustrated in their inability to speak Arabic. Indeed, as Savory notes, "the most important formative factor in creating the Arab consciousness is the Arabic language, which is the bearer of their culture, the vehicle of their history and the sacred tongue of the religion of the majority" (qtd in Nobles and Sciarra 4). vii Without access to Arabic, the children are, in fact, disinherited from the Arab world. viii

Like the speaker of "Heritage," the speaker of "Moving" did not grow up in the Middle East, but nevertheless considers it home: "it is when we are at sea this way / that I sometimes think about a life / I've never known except for a little while / in some old country of time that I remember my father and / grandfather / talking about, when I kept wanting to go out to play baseball." In conflating the father and grandfather with the "old country," the speaker deftly claims the Middle East as his native soil. ${ }^{\text {ix }} \mathrm{He}$ also gestures 
toward America with the image of himself as a boy waiting to play baseball while his family reminisces about the Arab world. His youthful desire to play baseball can be read as his assimilation into American culture. Indeed, baseball is the quintessential American game and pairing that with his family's stories of the Middle East indicates not merely a bicultural identity, but a cultural chasm, which, for the speaker, is growing more acute with time. As a father now, the speaker yearns for the strong family bonds prevalent in the Arab world, "where at least the whole tribe moved together." The emphasis on "together" marks another contrast to the family in America, in which they are described as "lost / shipmates crying. . . for help." The title of the poem, "Moving," has a layered meaning, evoking his family of origin's move from the Middle East to America, his children's move away from him and thus their Arabic roots and, more subtly, the title pays homage to the nomadic lifestyle of his "father and grandfather and their grandfather / before them." Implicitly, then, Hamod gestures towards Bedouins, as those who did not move away, but moved together.

That the speaker is uneasy with his physical separation from his children bespeaks a particular Arab worldview, namely that "Arabs do not see themselves primarily as individuals but rather as members of groups, especially family groups" (qtd. in Nobles and Sciarra 7). The term " 'worldview' comes from the German Weltanschauung, meaning a view or perspective on the world or the universe "used to describe one's total outlook on life, society and its institutions'" (Koltko-Rivera 3). Amplifying the term, it can be said that "in the largest sense, a worldview is the interpretive lens one uses to understand reality and one's existence within it" (KoltkoRivera 3). As an Arab, he subscribes to the unity of family; in fact, as Ali, Liu and Humedian note, "many Muslim societies tend to be collectivistic, and individualism and individuation from families is discouraged" (7). Arab societies are "built around the extended family system, creating a strong bond among blood relatives. Family is the first priority, exceeding obligations to work-an attitude understood by Arab employers, who will excuse an employee's absence or tardiness if family obligations or duties are involved" (Nobles and Sciarra 7). Put another way, "Arab families are "woven as tightly as a prize carpet" indeed, "for Arab Americans. . . the family is the self" (qtd. in Zoghby 22). This is particularly true in Bedouin society, where "the social unit is the group, not the individual. The latter has rights and duties only as a member of his group" (Lewis 24).

Clearly, cultural and ethnic beliefs are inextricable from one's worldview and thus the speaker of "Home" is caught in a liminal space, positioned, as he is, between his Arab worldview of family and an American worldview, which encourages independence and individuation. The multiple registries of movement literalize the speaker's tensions, as the family's immigration to America has resulted in the father's inability to live in accordance with his inherited worldview. ${ }^{x}$

Movement is the prism through which we enter Geha's short story collection, Through and Through as generations of Arabs move to and within America. In the collection, Arab immigrants and their offspring struggle to create home in Ohio, an important state in the history of the nation, as it marked the demarcation line between slavery and freedom during the antebellum period. Before the Fugitive Slave Act, a captive could claim physical freedom from bondage when crossing the Ohio River. It is apt, then, that the Yakoub family settles in a historic landscape of trauma, hope and new beginnings. ${ }^{\mathrm{x}}$ 
The short story collection pivots on the axis of death. In "Monkey Business," the protagonist Nazir's young wife passes, as does the street bum, Asfoori. In "News from Phoenix," Charlotte's unborn baby dies, and her husband, Erwin Klein is sick; the "news from Phoenix" will be of Erwin's death. Uncle Elias' beloved wife Maheeba dies in "And What Else," followed by a grief so profound it renders the old man silent; less than a month later, he, too, dies. And in "Holy Toledo," Nadia and Mikhail's young mother dies and the father abandons the children to live with their grandmother. Two stories in the collection, "Almost Thirty" and "Something Else" are narratives of mourning, where the protagonists struggle to make sense of their lives after their fathers' deaths. In the former, which Salaita rightly asserts is the most "complex story in Through and Through" (431), the narrator chronicles his life through death: "Uncle E and his wife died first. Then Jiddo Braheem's wife died of her old age. Aunt Yemnah died in Cleveland some years after that. The Greek Sophanakoluros died in rest home in Florida without my ever meeting him. George's parents, Aunt Anissa and Uncle Najeeb, had a baby boy when it was past their time, and the child died without ever seeing light and nearly took his mother with him. Uncle Najeeb died when George was still in grade school. Habeeb's first son was killed in the early days of Vietnam. Then in 1964, when I was almost thirty, my father died" (39). Death reverberates throughout the collection as members of the Yakoub family struggle to reconstruct their lives in the face of numerous losses. This is particularly difficult given the fact that these characters are also cut off from their homelands of Lebanon and Syria and thus each death registers a further loss of home. Literal deaths, then, have metaphoric implications in Geha's Through and Through, as immigration is itself encoded as a death experience. Indeed, in the titular story of the collection Geha provides a definition for the phrase "through and through," which references a kind of death with a handgun: "One round blew off his watch. The other eleven were what coroners listed as 'through and through'-in then right out the other side; clean, but they leave less evidence'" (Geha 119). This descriptor provides a key to understanding the many losses surrounding the immigrant experience. Because immigration is seen as a volitional act and popularly narrated, especially during the first part of the $20^{\text {th }}$ century (the time period when the collection takes place), as a move toward obtaining the "American Dream," the pain of dislocation is silenced; that is, the deadly blow leaves no evidence. Geha's work provides evidence for the fatal injury; in short, the casualties of immigration are concretized in literal deaths.

Arab immigrants have had a vexed relationship to U.S. citizenry, one which is complicated by their racial ambiguity: "Arabs in the United States fit uneasily into a racial schema that identifies individuals and groups as either 'black' or 'white.' The many studies on Arab American ethnicity and racial formation show that historically Arab Americans were first considered 'not white,' then 'not quite white,' then legally 'became white'" (Hartman 145). .ii $^{\text {Th }}$ This limal social and legal positionality, like all racial inscriptions, is based on the myth of racial polarities; nevertheless, given the hierarchies and privileges associated with whiteness, it follows that early Arab settlers desired the coveted racial designation. Here, it is tenable to review Arabs' assimilation into the larger American landscape, a shifting, complicated and ever evolving relationship that in recent years has been beset by wars and political tensions between Arabs' native land and their current homeland.

Paradigmatically, Arab American history is understood in three immigration waves, which are coterminous with diminishing allegiance to U.S. assimilation. The first wave of immigration, 1880-1924, was dominated by people who identified as Christians, 
Greek Orthodox, Syrians and Lebanese. As Ludescher avers, "Generally hardworking and law abiding, the [unskilled and largely illiterate] immigrants enthusiastically embraced American values" (93). The second wave of immigration, following World War II, from 1945-1967, consisted of educated professionals who were "more likely to be familiar with the nationalist ideologies that permeated the Arab world" and unlike the earlier settlers, these immigrants, "staunchly identified themselves as Arabs" (94). The third wave of immigration paralleled the second insofar as the settlers were far more politicized, "imbued with anti-colonial sentiment and Arab nationalist ideas" (94). This latter immigration, beginning in 1967 and continuing today, consisted of Muslim Lebanese and Palestinian who were displaced after the 1967 war with Israel. With this recent wave of immigration, a larger, more unified Arab American community has formed as "descendants of first- and second-wave immigrants joined the newly arrived countrymen in support of Arab concerns" (Ludescher 94). As Hartman offers: "Iong before September 11, 2001, issues on which Arab Americans expressed common ground with African Americans and other people of color have included: racial profiling; detention and murder for political organizing or even for the suspicion of political organizing; and the lynching of Arab Americans in the US South" (146). xiii From a historical perspective, Arabs have assimilated more readily into the United States; however, the higher percentage of Muslim immigrants, which Joseph rightly argues is "identified as a religion of color" (259), and the ongoing military strife between the United States and the Middle East has problematized the integration of Arabs in America.

In Through and Through, Geha forces the reader to see the damage wrought by homeland separation, yet his narrative does not remain stagnant in loss and grief; rather, the material carriers of home, namely food and drink, resituate the old world in the new. ${ }^{\text {xiv }}$ Food establishments, including Yakoub's Yankee Café and Grill, markets, coffee houses and butcher shops become the meeting ground for the Arab American community. "The shops themselves," as Salaita argues, "function as characters, serving as mediators among Arabs and non-Arabs, Old World values and American consumer culture" (430). For the immigrants and their children, food is a primary marker of family and culture. Indeed, in "Holy Toledo," Uncle Eddie Yakoub, back from the Navy, emblematizes his homecoming with the refrain, "The food, that's what I missed most" (87). Food, as that which nourishes and sustains, serves as a tangible symbol of home. Throughout the collection, characters eat, prepare, serve, talk about and sell Arabic food: rolled grape leaves, lamb meat ground with cracked wheat (kibbee), raw liver and onions, cracked wheat and parsley salad (tabouli), sheep tripe stuffed with rice and pine nuts simmered in a doughy sauce (ghammeh), tea with anise seeds (yensoun), pressed apricots, goat cheese, sesame paste, pine nuts, and briny olives are a connective thread in the stories, culinary metaphors that mirror the continuation of heritage, setting the stage for hyphenated identities to emerge. For the Arab American reader, Geha's gesture of naming Arabic fare is itself an act of homecoming.

In the conclusion of "Almost Thirty," two young male cousins fall in love and marry American women. Notably, Geha uses food as a metaphor for their cultural dislocation: "The family received our wives, but not easily. After all, they were Americans. They could not make phtire or tabouli, and they both cringed at the sight of raw liver with onions. My wife tried to make kibbee once, but it turned to concrete in your stomach. So, to this day, George and I eat egg salad sandwiches at family picnics. 
'The kibbee is not important,' we tell the others, and they shake their heads to see us eat the egg salad" (46). With the American wives come dissolution of their old world character and the adoption of an American national identity, as egg salad sandwiches are a decidedly all-American fare. The cousins are not merely eating egg salad sandwich, but are ingesting and thus becoming part of the American landscape, just as their offspring surely will. ${ }^{\mathrm{x}}$ As if to reassert their hyphenated identities, the men move from tasting their cultural exile to dancing the debkee to the beat of small Arab drums: "He threw down his egg salad sandwich and he stood up, and his wife stood up with him. The four of us locked arms. I showed them the steps as best I could. Then, with our arms locked, we broke into dance" (47).

Food as a portable marker of home likewise is suggested in Syrian American poet, Mohja Kahf's "The Skaff Mother Tells the Story" and "Word from the Younger Skaff." In the former, the mother and father send their two young sons away to save them from being conscripted to fight in war; however, the mother, with little time to prepare for this sudden journey, sends what she can with her boys, namely mincemeat pies, wrapped in a wool scarf. The mother, heartbroken, exclaims, "We sent them away, I I swear, to keep them with us; they were only boys." In the following poem, written as a response to the mother's plaintive call, the son begins, "I was still hungry I when I left home, mother, / to disappear from the one piece / of earth I knew." The speaker goes on to use the metaphor of food ("the night we left. . . was dinnertime") to indicate the hunger he feels for his family, home and native land. Despite living in Brazil, his daughter, who has inherited his mother's "hair and eyes" "knows how / to make [her] mincemeat pies." Significantly, his wife never learned to make this dish, suggesting the role that blood memory plays in the continuation of ancestry and culture. The daughter's Syrian meat pies are "baked golden and sealed / with [the mother's] same thumbpress" a literal imprint of body onto food. The material marker of familial love that the mother provides for her young sons becomes the text of embodied ethnicity, which her granddaughter inherits.

Of all the food and drink items in Geha's Through and Through, coffee is the most prominent. As a recurring symbol, it punctuates the stories in the collection: "And there were the ahwa shops, where the old men sat all day amid tobacco smoke and the bitter smell of Turkish coffee" (87); "Throughout the funeral, throughout the mourning and the time of quiet that followed my father's death, George stayed by me and worried over me like a little brother. He brought me cigarettes and coffee, sat up with me in my room till all hours when neither of us had anything to say" (39); and "After dinner they had coffee, laughing at Father's stories about the seminary and the old priest who taught there" (57).

This is an important symbol, as coffee originated in "the ancient land of Abyssinia, now called Ethiopia," which is "situated at the conjunction of the African and Arab worlds" (Pendergrast 3). In fact, an Arab physician, Rhazes, in the $10^{\text {th }}$ century is responsible for the first written account of coffee; however, the coffee plant (and caffeine's effects on the body) had been the subject of folktales for hundreds of years beforehand (Pendergrast 4, 5). ${ }^{x v i}$ Coffee spread throughout the Arab world before making its way to Europe and the Americas. The Arabs "began cultivating the trees, complete with irrigation ditches, in the nearby mountains, calling it qahwa, an Arab word for wine-from which the name coffee derives" (Pendergrast 6). Although initially used for medicinal or religious use (Arab Sufi monks drank a brewed coffee beverage 
because it enabled them to stay awake for midnight prayers), it wasn't long before coffee consumption began on a widespread basis throughout the Arab world. Indeed, wealthy families had special coffee rooms in their homes and a number of coffee houses (known as kaveh kanes) spread throughout Persia, Egypt, Turkey and North Africa:

Coffee houses allowed people to get together for conversation, entertainment, and business, inspiring agreements, poetry, and irreverence in equal measure. So important did the brew become in Turkey that a lack of sufficient coffee provided grounds for a woman to seek divorce.

\section{(Pendergrast 7)}

Since some Islamic rulers believed that coffee houses were the meeting place for rebellious activity, there were a series of edicts banning the beverage. Despite such laws, coffee continued to be drunk and the bans were eventually lifted. Coffee became so conflated with the Arab world that it was considered by Europeans a Muslim or Arabian drink. ${ }^{\text {xvii }}$ In that way, coffee became, itself, a symbol of Arabs: "Pope Clement VIII, who died in 1605, supposedly tasted the Moslem drink at the behest of his priests, who wanted him to ban it. 'Why, this Satan's drink is so delicious,' he reputedly exclaimed, 'that it would be a pity to let the infidels have exclusive use of it. We shall fool Satan by baptizing it and making it a truly Christian beverage"' (Pendergrast 8). Thus, when coffee spread to Europe in the seventeenth century, it still was considered an exotic beverage, and "like other such rare substances as sugar, cocoa, and tea, [it] initially was used primarily as an expensive medicine by the upper classes" (Pendergrast 8).

The historic relationship between the Arab world and coffee is significant even today; coffee is a popular beverage throughout the Middle East, as are coffee houses where people go for conversation, to play dominoes or backgammon. Moreover, the involved preparation of Arabic coffee (known also as Turkish coffee) suggests the import of the drink: "In an elaborate social ritual, coffee was brought to boil three times in the ibrik (a small conical copper pot with a long handle) before the viscous drink was dispensed into small cups, the pourer carefully shaking his hand so that a little wesh, or froth, topped each cup" (Pendergrast 7). Geha, who uses coffee throughout his collection, mentions "Turkish coffee" in "Something Else" and in so doing gestures towards the weight of the occasion: "In the kitchen Mama helps with the coffee. Tonia can hear her in there, telling the other women about Papa and how in the old country her parents had first arranged for him to visit and have Turkish coffee" (51).

The ceremonial aspect of preparing and drinking Arabic coffee also is given voice in Naomi Shihab Nye's "Arabic Coffee." In this poem, Nye's father performs the coffee making ritual: "Leaning over the stove, he let it / boil to the top, and down again. / Two times." Capturing the special moment, Nye writes: "When he carried the tray into the room, / high and balanced in his hands, / it was an offering to all of them, / stay, be seated, follow the talk / wherever it goes. The coffee was / the center of the flower." As an "offering," the "center," coffee elicits fellowship and conversation. More importantly, the act of sharing coffee, a familiar image of hospitality in Arab American letters, is not a hastened activity, but is an act of communion. 
The first story in Geha's Through and Through, "Monkey Business," epitomizes coffee as a brew of the Middle East and hence a text of home. Further, in this piece, drinking coffee becomes a substitute for emotion. "Monkey Business" centers on immigrant Nazir (Zizi) Yakoub's impending marriage to Uhdrah, a fanatical Christian from Lebanon. This arranged marriage is not based on Zizi's desire to remarry; rather, it is intended to fill the void of his late wife, Samira, for their five-year-old son, Jameel, an old-world tradition that Zizi feels honor-bound to maintain. The intimacy between husband and wife is conveyed twice through the metaphor of coffee: "He used to walk home after a day like that, and Samira would be there. She unlaced his shoes for him. She poured coffee-always there was coffee-then she would sit with him at the kitchen table" (4). In the second incident, coffee marks his wife's absence: "A bedroom, a front room, a tiny kitchen, but when Samira was alive it had been a home. . . Even now the memory if it remains, centered and epitomized in the one remembered image of a cup of coffee, Samira sitting at the kitchen table, drinking a cup of coffee" (3). While the economy of these scenes may lead the reader to dismiss their import, coffee is used in two other significant, transitional moments in the story. Prior to proposing to Udrah, Zizi asks for coffee (10) and after their marriage is called off, signaling Zizi's permanent status as a single parent, Jameel comforts his father, removing his wet coat and shoes and brewing coffee. The scent of coffee in the apartment comforts Zizi and reminds him of his late wife, which, he muses, is "enough." The familiar scent of coffee reassures both father and son of home.

Although Samira's death is the primary loss in "Monkey Business," a minor character, Asfoori, the street bum, who is given no voice in the story, also dies and his funeral is, perhaps not surprisingly, paired with coffee, as Braheem remarks: "'He's dead, right? So where's the coffee?"' (15). Drinking coffee at these profound moments arcs back to the larger loss of home; thus, employing the symbol of coffee suggests an attempt to mitigate loss, writ large, with assurances of home.

Home in Geha's Through and Through is conceptually linked to bell hooks' notion of homeplace specifically as the interiority of the home offers renewal, recovery and healing in the midst of oppression and domination. hooks historicizes the import of home in African America culture: "African American women believed that the construction of a homeplace however fragile and tenuous (the slave hut, the wooden shack), had a radical political dimension. Despite the brutal reality of racial apartheid, of domination, one's homeplace was the one site where one could freely confront the issue of humanization, where one could resist" (hooks 42). In this way, Arab Americans, who often experience their position in America as provisional and uneasy, explicitly in times of national crisis, turn to those aspects of home to provide safety and, according to hooks, resistance: "we can make homeplace that space where we return for renewal and self-recovery, where we can heal our wounds and become whole" (hooks 49). The many articles that comprise home in Geha's Through and Through, while seemingly insignificant, bridge the geo-cultural gap.

Throughout the short story cycle, Geha reminds readers that home is a complex negotiation of place, geography, memory and politics. By remembering and imagining an Arab past, Arab American writers who seemingly have assimilated into the country in which they or their families have migrated, maintain a political and ideological connection to the Middle East manifest in the food they eat, drinks they imbibe and the 
words they speak. That there is a fraught relationship between the home of their ancestors (the Middle East) and the home of their children (the United States) exemplifies home as a shifting terrain of belonging and exile, disinheritance and yearning. By privileging the portable aspects of home, Arab American authors, sojourners searching for a larger place of belonging, implicitly gesture toward the Bedouin. Mapping homelands beyond the limits of national borders and imagining the possibility of dwellings that are imprinted with geographies of the past, allows Arab American writers, modern day Bedouins, to construct home.

\section{Works Cited}

Abu-Lughod, Lila. "Sad Songs of the Western Desert." Everyday Life in the Muslim Middle East. Eds. Bowen, Donna Lee and Evelyn A. Early. Bloomington, Indiana UP, 2002. 281-286.

Akash, Munir and Khaled Mattawa. "Introduction." Post-Gibran: Anthology of New Arab American Writing. Eds. Munir Akash and Khaled Mattawa. Syracuse: Syracuse University Press, 1999. xi-xiii.

Ahmed, Saladin. "Poem for Countee Cullen." Post Gibran: Anthology of New Arab American Writing. Eds. Munir Akash and Khaled Mattawa. Syracuse: Syracuse University Press, 1999. 255-256.

Ali, Saba Rasheed, William Ming Liu and Majeda Humedian. "Islam 101: Understanding the Religion and Therapy Implications." Professional Psychology: Research and Practice. 35.6 (December 2004): 1-16.

Cullen, Countee. "Heritage." African American Literature. Eds. Keith Gilyard and Anissa Wardi. New York: Longman, 2005. 1254-1257.

Elia, Nada. "Islamophobia and the 'Privileging' of Arab American Women. NWSA Journal. Fall 18.3 (2006): 155-161.

Geha, Joseph. Through and Through: Toledo Stories. Saint Paul, Graywolf Press, 1990.

Hamod, H. S. "Moving." Grapeleaves: A Century of Arab American Poetry. Eds. Orfalea, Gregory and Sharif Elmusa. Salt Lake City: University of Utah Press, 1988. 175-176.

Hartman, Michelle. "'This sweet / sweet music" Jazz, Sam Cook, and Reading Arab American Literary Identities." MELUS. 31.4 (Winter 2006): 145-165).

hooks, bell. Yearning: Race Gender $_{\perp}$ and Cultural Politics. Boston: South End Press, 1990.

Hourani, Albert. A History of the Arab Peoples. Cambridge: Belknap Press of Harvard UP, 2002. 
Johnson, Erica L. Home, Maison, Casa: The Politics of Location in Works by Jean Rhys,

Marguerite Duras, and Erminia Dell'Oro. Madison, Fairleigh Dickinson UP, 2003.

Joseph, Suad. "Against the Grain of the Nation-The Arab." Arabs in America: Building a New Future. Ed. Michael W. Suleiman. Philadelphia: Temple University Press, 1999. 257-271.

Kadi, Joanna, Ed. Food for Our Grandmothers: Writings by Arab-American and Arab-Canadian Feminists. Ed. Joanna Kadi. Boston: South End, 1994.

Kahf, Mohja. "I Can Scent an Arab Man a Million Miles Away." E-mails from Scheherazad. Gainesville: University Press of Florida, 2003. 29-30.

--. "The Skaff Mother Tells the Story." E-mails from Scheherazad. Gainesville: University Press of Florida, 2003. 2-3.

--. "Word for the Younger Skaff." E-mails from Scheherazad. Gainesville: University Press of Florida, 2003. 4-5.

Koltko-Rivera, Mark E. Review of General Psychology. 8.1: (March 2004): 1-83.

Lewis, Bernard. The Arabs in History. Oxford: Oxford UP, 1993.

Ludescher, Tanyss. "From Nostalgia to Critique: An Overview of Arab American Literature." MELUS 31.4 (Winter 2006): 93-114.

Majaj, Lisa Suhair. "Arab American Literature and the Politics of Memory." Memory and Cultural Politics: New Approaches to Ethnic Literatures. Boston: Northeastern UP, 1996.

Musallam, Basim. The Arabs: A Living History. London: Harvill Press, 1983.

Nobles, Anna Y., Daniel Sciarra T. "Cultural Determinants in the Treatment of Arab Americans: A Prime for Mainstream Therapists." American Journal of Orthopsychiatry. 70.2 (April 2000): 1-16.

Nye, Naomi Shihab. "Arabic.” 19 Varieties of Gazelle. New York: HarperCollins, 2002. 90-91.

--. “Arabic Coffee." 19 Varieties of Gazelle. New York: HarperCollins, 2002. 38-39.

--. "Red Brocade." 19 Varieties of Gazelle. New York: HarperCollins, 2002. 40-41.

Orfalea, Gregory and Sharif Elmusa. "Introduction." Grapeleaves: A Century of Arab American Poetry. Eds. Orfalea, Gregory and Sharif Elmusa. Salt Lake City: University of Utah Press, 1988. 
Pendergrast, Mark. Uncommon Grounds: The History of Coffee and How It

Transformed our World. New York: Basic Books, 1999.

Salaita, Steven. "Sand Niggers, Small Shops, and Uncle Sam: Cultural Negotiation in the

Fiction of Joseph Geha and Diana Abu-Jaber." Criticism. 43.4 (Fall 2001): 423444.

Suleiman, Michael. W. "Introduction: The Arab Immigrant Experience." Ed. Suleiman, Michael. W. Arabs in America: Building a New Future. Philadelphia: Temple UP, 1999.

Zoghby, Mary D. "Memory, Image and Identity in Arab American Poetry." Paintbrush Spring (1991): 21-28.

Stories of elderly Palestinian holding onto keys to houses that have long been bulldozed by Israeli troops underscore the indelible relationship between home and identity in the Arab world.

i" In the West the Bedouin has served to emblematize the exotic Arab "other." In The English Patient, for example, the Bedouins appear as if by magic to work some sorcery and then disappear. Therefore, like the mythic Genie in a bottle, this Arab other only serves the purpose of the West and then vanishes so as to not disrupt the order. There is no individual identity of the Bedouin; his appearance merely reinforces the Orientalist view of the Arab as exotic, different and especially non-Western.

iii The reference to the tent is a material reference to the Bedouin's home. A Bedouin's tent is fairly standard-the exterior is made of woven, black goat hair and the interior is dominated by a large colorful scarf separating men's quarters from women's.

iv Early Bedouins resisted conversion to Islam: "The system [Muhammad] offered was alien to them, demanding a renunciation of their intense love of personal independence and of an important part of their established code of virtue and ancestral traditions" (Lewis 43). Their religion was communal and their gods "were in origin the inhabitants and patrons of single places, living in trees, fountains, and especially in sacred stones" (Lewis 25). That Bedouins were steeped in ancestral spiritual practices underscores their relevance as early ancestral figures for both Christian and Muslim Arab Americans.

$\checkmark$ Expressing some of their most poignant sentiments, Bedouin poetry creates intimacy within the community insofar as the listeners recognize that this oral lyric poetry, sung equally by men and women, is a testament to the hardship of their lives (Abu-Lughod 283).

vi. "Within the Arab- American literary scene, there is much more poetry than fiction" (Akash and Mattawa xiii), and numerous reasons are hypothesized for writers' penchant for this genre, not the least of which is the relationship of Arab American writers to the 
Middle East. Because poetry is, by far, the favored art form of Arab American writers, Orfalea and Elmusa theorize that ancestral memory is at play: "the great Arab love of poetry has not been drained from New World veins" (xv). However, it should be noted that critics, such as Majaj, argue that this kind of discourse, which articulates Arab identity in terms of essentialist rhetoric, does not allow for complex cultural differences (271).

vii Palestinian American poet, Naomi Shihab Nye, also recognizes the seminal role that language plays in Arab identity and thus in her poem, "Arabic," the man with the "laughing eyes" tells Nye, "Until you speak Arabic, / you will not understand pain"'. Nye, though, does not have full access to her father language: "I admit my / shame. To live on the brink of Arabic, tugging / its rich threads without understanding / how to weave its rug. . . I have no gift" (91). Because she believes her "gift" of heritage is stunted by her inability to speak Arabic, she cannot speak its pain, cannot be its witness. However, by the poem's end, the speaker admits to "feeling sad" and responds to the man, "I'll work on it." Nye's desire to "work on" Arabic suggests that she cannot fully articulate the pain of her people without speaking their language.

vii The children's inability to speak Arabic is historically relevant, for "whereas first generation Arabs in America managed as best they could in an alien environment, their children were thoroughly immersed in American society and culture-and their first or only language was English" (Suleiman 5)

ix It should be noted that home is not an elusive construct in these works, but is placed, geographically and geopolitically, in the Arab world. While many postcolonial theorists critique nationalist discourse, nationalism and especially pan-Arabism continues to have ideological currency for Arab Americans. Identification through the Arab nation-state is particularly significant at this cultural moment, as Arabs are identified, as a group, in opposition to western colonial rule, exemplified through America's continuing support of Israeli occupation of Palestine and the wars in Iraq.

"While the speaker of "Moving" is Muslim and the characters in Geha's Through and Through are Christian, as Arabs they share similar cultural norms. Though there is a conflation of Arabs and Islam, the majority of Muslims are not Arabs and "most Arab immigrants of the first wave [from the 1870s to World War II] came from the Great Syria region, especially present-day Lebanon, and were overwhelmingly Christian" (Suleiman 1).

xi The references to African American history are not intended as a conflation of African American and Arab American experiences, the former being a forced migration into enslavement. Rather, Arab American immigration is inflected with the experiences of other groups of color in America (hence the common racist epithet "Sand Nigger" directed at Arabs), and is used here to contextualize issues of alienation and displacement.

xii For more information about Arab racial categorization, please see our essay, "In Passing: Arab American Poetry and the Politics of Race."

xiii It must be stated that while some Arab Americans actively seek political and cultural alliance with communities of color, other Arabs, with more conservative political leanings, stake claim to their legal status of white. Arabs are not a monolithic community and therefore this argument rests on trends and not on absolutes.

xiv Food is a primary symbol for Arab American authors. In fact, two significant Arab American anthologies highlight food in their titles: Grapeleaves: A Century of Arab American Writing and Food for Our Grandmothers: Arab American and Arab Canadian Feminist Writing. Each section of the latter book provides recipes for Arabic cuisine. 
These staples, including, olives, grapeleaves and laban, provide a cultural lens with which to read the literary outpouring. Despite the many differences among Arab peoples, food suggests a familiar terrain of family and culture.

${ }^{x}$ This trajectory of marrying American and losing touch with one's ethnicity is made clear in "Monkey Business" as Jameel, the young boy, claims that "he would marry an Amerikani woman. . . and teach his children to speak only Ingleez." At this thought, the "pleasure immediately drained from Braheem's face" (5).

xi One popular legend recounts the exploits of a goat herder, named Kaldi, whose goats were dancing one day after eating a type of red cherry. The next day Kaldi tried the berry, himself, and was much energized, playing alongside his goats, while "poetry and song spilled out of him" (Pendergrast 4). Although the veracity of this tale is not confirmed, it is told often as the first account of coffee consumption.

xvii In the late nineteenth century, Hills Brothers Coffee, sold in San Francisco, commissioned an ad to be developed to sell their coffee. Even though most of Hills Brothers beans "arrived from Central America and Brazil," the ad icon was "a turbaned, bearded Arab in a flowing robe" sipping coffee (Pendergrast 125), again underscoring the relationship between coffee and the Middle East 